\title{
ANALISA PENGARUH KOMPETENSI, DISIPLIN KERJA, DAN KOMPENSASI TERHADAP KINERJA KARYAWAN PADA PT. MORANTHEL INDONESIA GEMILANG
}

\begin{abstract}
ABSTRAK
Email : emas781@gmail.com

ANALISA PENGARUH KOMPETENSI, DISIPLIN KERJA, DAN KOMPENSASI TERHADAP KINERJA KARYAWAN PADA PT. MORANTHEL INDONESIA GEMILANG. Tujuan penelitian ini adalah untuk menganalisis pengaruh secara parsial maupun simultan antara Kompetensi, Disiplin Kerja, Dan KompensasiTerhadap Kinerja Karyawan Pada PT Moranthel Indonesia Gemilang Tangerang. Metode dalam penelitian ini berjenis asosiatif dengan pendekatan deskriptif dan kuantatif. Populasi dan sampel dalam penelitian ini sebanyak 108 responden dan menggunakan teknik sampling sensus untuk menentukan jumlah sampel. Hasil penelitian menunjukkan bahwa hasil uji t (uji Parsial) pada variabel bebas Kompetensi $\left(X_{1}\right)$, Disiplin Kerja $\left(X_{2}\right)$ dan Kompensasi $\left(X_{3}\right)$ diperoleh nilai $t_{\text {hitung }}$ sebesar 3,335 untuk $X 1$, untuk X2 diperoleh nilai thitung sebesar 3,316 dan untuk X3 diperoleh nilai thitung sebesar 4,158, sedangkan nilai $t_{\text {tabel }}=1,983(n=108 ; p=5 \%)$. Sedangkan nilai koefisien signifikan untuk ketiga variabel bebas nilainya lebih kecil dari 0,05 . Hasil uji secara simultan (uji $F$ ) antara Kompetensi $\left(\mathrm{X}_{1}\right)$, Disiplin kerja $\left(\mathrm{X}_{2}\right)$, dan Kompensasi $\left(\mathrm{X}_{3}\right)$ terhadap Kinerja $(\mathrm{Y})$ menunjukan nilai $F_{\text {hitung }}$ sebesar 11,997 $>F_{\text {tabel }} 2,69$ dengan nilai probabilitas Sig $0,000<0,05$ dengan nilai koefisien determinasi sebesar 25,7\%. Berdasarkan hasil perhitungan tersebut di atas maka dapat disimpulkan bahwa Kompensasi, Disiplin Kerja dan Kompensasi secara parsial maupun simultan berpengaruh signifikan terhadap Kinerja karyawan. Kontribusi atau sumbangan kompetensi, disiplin kerja dan kompensasi terhadap kinerja sebesar $25,7 \%$ dan sisanya $74,3 \%$ dipengaruhi oleh faktor lain.
\end{abstract}

Dayat Hidayat ${ }^{*}$, Eka Maya Sari SC ${ }^{\star *}$, Jaya Selwan ${ }^{\star * *}$

Kata Kunci : Kompetensi, Disiplin Kerja, Kompensasi dan Kinerja

\begin{abstract}
ANALYSIS OF THE EFFECT OF COMPETENCE, WORK DISCIPLINE, AND COMPENSATION ON EMPLOYEE PERFORMANCE IN PT. MORANTHEL INDONESIA GEMILANG. The research aims to examine and analyze the effect partially or simultaneously between Competence, Work Discipline, and Compensation on Employee Performance at PT Moranthel Indonesia Gemilang Tangerang. The method in this research is associative with descriptive and quantative approaches. The population and sample in this research were 108 respondents and used census sampling techniques to determine the number of samples. The results showed that the results of the $t_{\text {test }}$ (Partial test) on the independent variable Competence (X1), Work Discipline (X2) and Compensation (X3) obtained a $t_{\text {count }}$ of 3.335 for $X 1$, for $X 2$ obtained a tcount of 3.316 and for $X 3$ obtained value $t$ count of 4.158, while the value of ttable $=1.983(n=108 ; p=5 \%)$. While the significant coefficient value for the three independent variables is less than 0.05 . Simultaneous test results $\left(F_{\text {test }}\right)$ between Competence $(X 1)$, Work Discipline (X2), and Compensation (X3) on Performance $(Y)$ show a calculated $F_{\text {test }}$ of 11,997> $F_{\text {table }} 2.69$ with a probability value of Sig $0,000<0,05$ with the coefficient of determination is $25.7 \%$. Based on the results of the calculation above, it can be concluded that Compensation, Work Discipline and Compensation partially or simultaneously have a significant effect on employee performance. Contribution of competence, work discipline and compensation for performance is $25.7 \%$ and the remaining $74.3 \%$ is influenced by other factors.
\end{abstract}

Keywords: Competence, Work Discipline, Compensation and Performance

*) dan **) Dosen Program Studi Magister Manajemen - UNPAM

***) Mahasiswa Program Studi Magister Manajemen - UNPAM 


\section{PENDAHULUAN}

\section{A. Latar Belakang Masalah}

Kinerja Pengahasilan PT. Moranthel Indonesia Gemilang mengalami penurunan dalam dua tahun belakangan, penurunan kinerja ini disebabkan oleh kinerja karyawan. Untuk lebih lanjut melihat faktor -faktor apa saja yang mempengaruhi Kinerja Karyawan pada PT.Morathel Indonesia Gemilang maka diduga Kompetensi , Disiplin Kerja, Dan Kompensasi berpengaruh pada Kinerja Karyawan pada PT. Morathel Indonesia Gemilang.

Dalam meningkatkan upaya pengembangan karyawan, perusahaan dihadapkan dengan hasil kerja pada karyawan yang berkerja. Baiknya hasil kerja karyawan akan meningkatkan kinerja kerja perusahaan jangka pendek dan jangka panjang. PT. Moranthel Indonesia Gemilang, dari pengamatan yang dilakukan di tempat penelitian, kinerja karyawan terlihat masih naik turun. Hal ini terlihat dari tabel pencapaian kinerja organisasi dinilai tidak produktif. Berikut tabel pencapaian pendapatan perusahaan.

Tabel 1.1 : Target dan Realisasi Perusahaan

\begin{tabular}{|l|cc|c|c|}
\hline Tahun & Target & Realisasi & \multicolumn{1}{c|}{$\%$} \\
\hline 2015 & $\operatorname{Rp~} 15,000,000,000$ & $\operatorname{Rp~15,475,456,000}$ & $103 \%$ \\
\hline 2016 & $\operatorname{Rp~} 15,000,000,000$ & $\operatorname{Rp~14,894,587,000}$ & $99 \%$ \\
\hline 2017 & $\operatorname{Rp~15,000,000,000~}$ & $\operatorname{Rp~11,588,948,000}$ & $77 \%$ \\
\hline
\end{tabular}

Sumber : PT Moranthel Indonesia Gemilang 2018

Dari tabel di atas menunjukkan bahwa, target tahun 2015 mencapai target dengan persentasae $103 \%$, pada tahun 2016 perusahaan tidak mencapai target pendapatan dan hanya mencapai 99\%, dan pada tahun 2017 tingkat pendapatan semakin menurun menjadi $77 \%$ dari target yang terealisasi.

Menurunnya pendapatan perusahaan bukan tanpa sebab, hal ini dikarenakan minimnya produktifitas kerja karyawan, dimana perusahaan tidak dapat menyelesaikan pesanan produk dalam jumlah besar, sehingga sering menolak order dari konsumen yang mengakibatkan menurunnya pendapatan perusahaan. Tidak sanggupnya perusahaan dalam menyelesaikan produk pesanan dalam jumlah besar dikarenakan kompetensi yang dimiliki karyawan dari segi pengetahuan dan keterampilan karyawan masih terbilang kurang, sehingga mengganggu jalannya proses pelaksanaan pekerjaaan.

Tingkat pendidikan merupakan faktor penting utama dalam menunjang efektivitas kinerja karyawan. Karyawan di kantor PT. Moranthel Indonesia Gemilang memiliki latar belakang pendidikan yang berbeda. Berikut data tingkat pendidikan karyawan di PT. Moranthel Indonesia Gemilang pada tahun 2018. Adapun tingkat pendidikan karyawan PT. Moranthel Indonesia Gemilang Tahun 2018

Tabel 1.2 : Tingkat Pendidikan Karyawan 2018

\begin{tabular}{|l|c|c|c|c|}
\hline \multirow{2}{*}{ Divisi Karyawan } & \multicolumn{3}{|c|}{ Tingkat Pendidikan } & Jumlah \\
\cline { 2 - 4 } & SMP & SMU & Sarjana & Karyawan \\
\hline Office Staff & 3 & 24 & 7 & 34 \\
\hline Marketing/Sales & 0 & 8 & 4 & 12 \\
\hline Staff Produksi & 9 & 27 & 2 & 38 \\
\hline
\end{tabular}




\begin{tabular}{|c|c|c|c|c|}
\begin{tabular}{|c|c|c|} 
Pekerja Harian Lepas (Non Staff \\
Bag Produksi)
\end{tabular} & 8 & 16 & 0 & 24 \\
\hline Jumlah & $\mathbf{2 0}$ & $\mathbf{7 5}$ & $\mathbf{1 3}$ & $\mathbf{1 0 8}$ \\
\hline Persentase & $\mathbf{1 9 \%}$ & $\mathbf{6 9 \%}$ & $\mathbf{1 2 \%}$ & \\
\hline
\end{tabular}

Sumber : PT Moranthel Indonesia Gemilang 2018

Dari tabel di atas menunjukkan bahwa, mash terdapat $19 \%$ karyawan dan non karyawan yang berpendidikan SMP.Sedangkan karyawan yang berpendidikan SMU sebesar $69 \%$ dan $12 \%$ berpendidikan Sarjana.Hal ini menunjukkan masih rendahnya kompetensi karyawan dalam hal pendidikan.

Tingkat kedisiplinan karyawan dapat terlihat dari Tabel 1.3 dibawah ini:

Tabel 1.3 : Absensi Karyawan PT. Moranthel Indonesia Gemilang

\begin{tabular}{|l|c|c|c|c|c|c|c|c|c|}
\hline \multirow{2}{*}{ Bulan } & \multicolumn{3}{|c|}{2015} & \multicolumn{3}{|c|}{2016} & \multicolumn{3}{c|}{2017} \\
\cline { 2 - 10 } & Sakit & Terlambat & $\begin{array}{c}\text { Tanpa } \\
\text { Ket }\end{array}$ & Sakit & Terlambat & $\begin{array}{c}\text { Tanpa } \\
\text { Ket }\end{array}$ & Sakit & Terlambat & $\begin{array}{c}\text { Tanpa } \\
\text { Ket }\end{array}$ \\
\hline Januari & 5 & 3 & 4 & 6 & 2 & 4 & 2 & 3 & 4 \\
\hline Februari & 4 & 4 & 2 & 3 & 3 & 3 & 3 & 2 & 4 \\
\hline Maret & 6 & 4 & 2 & 4 & 4 & 2 & 3 & 2 & 3 \\
\hline April & 4 & 5 & 1 & 5 & 4 & 4 & 2 & 3 & 2 \\
\hline Mei & 6 & 4 & 2 & 6 & 5 & 4 & 2 & 4 & 3 \\
\hline Juni & 9 & 4 & 3 & 5 & 4 & 2 & 3 & 4 & 2 \\
\hline Juli & 2 & 3 & 3 & 15 & 5 & 3 & 3 & 4 & 3 \\
\hline Agustus & 5 & 3 & 8 & 12 & 4 & 5 & 4 & 5 & 3 \\
\hline September & 5 & 3 & 1 & 3 & 4 & 4 & 4 & 6 & 4 \\
\hline Oktober & 4 & 4 & 2 & 4 & 4 & 6 & 5 & 5 & 4 \\
\hline November & 3 & 5 & 2 & 5 & 5 & 2 & 5 & 5 & 3 \\
\hline Desember & 8 & 2 & 4 & 12 & 6 & 1 & 8 & 10 & 6 \\
\hline Jumlah & $\mathbf{6 1}$ & $\mathbf{4 4}$ & $\mathbf{3 4}$ & $\mathbf{8 0}$ & $\mathbf{5 0}$ & $\mathbf{4 0}$ & $\mathbf{4 4}$ & $\mathbf{5 3}$ & $\mathbf{4 1}$ \\
\hline
\end{tabular}

Sumber : PT Moranthel Indonesia Gemilang 2017

Dari tabel di atas menunjukkan bahwa, masih adanya karyawan yang kurang disiplin dalam keterlambatan dan ketidakhadiran karyawan. Sepanjang tahun 2015 jumlah karyawan yang sakit terdapat 61 karyawan, meningkat pada tahun 2016 menjadi 80 karyawan dan menurun menjadi 44 karyawan pada tahun 2017, keterlambatan karyawan pada tahun 2015 terdapat 44 karyawan, meningkat pada tahun 2016 menajadi 50 karyawan dan menurun menjadi 53 pada tahun 2017. Keterlambatan karyawan tahun 2015. Karyawan tanpa keterangan atau tidak masuk tanpa memberikan keterangan pada tahun 2015 terdapat34 karyawan, pada tahun 2016 meningkat 40 karyawan dan pada tahun 2017 meningkat menjadi 41 karyawan.

Pemberian kompensasi di rasa masih belum memenuhi kesejahteraan karyawan, khususnya pada pemberian pensiun/pesangon. Dimana pemberian uang pensiun/pesangon perusahaan tidak memberikan kepada karyawan. Selain itu asuransi yang diberikan hanya BPJS. Dari segi pemberian insentif kehadiran perusahaan tidak ada dan hanya memberikan upah lembur bila karyawan lembur di hari libur kerja ataupun melebihi jam kerja operasional. Hal ini jelas berbeda dengan peraturan perundang-undangan menteri tenaga kerja yang telah dikeluarkan. 
Tabel 1.4 : Jenis Pemberian Kompensasi

\begin{tabular}{|l|l|l|}
\hline No & Jenis Motivasi Finansial & Ket \\
\hline 1 & BPJS (Badan Penyelenggaran jasmani kesehatan) & Ada \\
\hline 2 & Asuransi kesehatan dan JKK (jaminan kecelakan kerja) & Tidak Ada \\
\hline 3 & Pensiun/Pesangon & Tidak Ada \\
\hline 4 & THR & Ada \\
\hline 5 & Upah Lembur & Ada \\
\hline 6 & Insentif Kehadiran & Tidak Ada \\
\hline
\end{tabular}

Sumber : PT Moranthel Indonesia Gemilang 2017

Berdasarkan uraian diatas, maka peneliti sangat tertarik untuk melakukan penelitian dengan judul "Analisis Pengaruh Kompetensi, Disiplin Kerja, dan Kompensasi terhadap Kinerja Karyawan pada PT. Moranthel Indonesia Gemilang Tangerang“"

\section{B. Identifikasi Masalah}

Dari uraian diatas, maka dapat diidentifikasi permasalahan-permasalahan yang perlu dikaji, diantaranya :

1. Masih kurangnya pengetahuan karyawan yang dilihat dari tingkat pendidikan karyawan.

2. Masih adanya karyawan yang tidak berpengalaman saat proses perekrutan

3. Tingkat kehadiran Karyawan PT. Moranthel Indonesia Gemilang belum sesuai harapan.

4. Pemimpin yang kurang tegas dan kurang melakukan pengawasan dan evaluasi kinerja karyawan

5. Kompensasi yang di berikan PT. Moranthel Indonesia Gemilang belum sesuai harapan karyawan.

6. Kurangnya penghargaan yang diberikan kepada karyawan yang berprestasi.

7. Kinerja karyawan yang masih belum sesuai dengan target yang telah ditetapkan

8. Masih rendahnya keterampilan karyawan dalam pelaksanaan pekerjaan

\section{Perumusan Masalah}

Permasalahan yang diteliti adalah pengaruh variabel Kompetensi, kedisiplinan, dan kompensasi terhadap kinerja karyawan pada PT. Moranthel Indonesia Gemilang yang menimbulkan beberapa pertanyaan untuk penelitian ini sebagai berikut :

1. Apakah kompetensi berpengaruh signifikan terhadap kinerja karyawan pada PT. Moranthel Indonesia Gemilang?

2. Apakah disiplin kerja karyawan berpengaruh signifikan terhadap kinerja karyawan padaPT. Moranthel Indonesia Gemilang?

3. Apakah kompensasi berpengaruh signifikan terhadap kinerja karyawan pada PT. Moranthel Indonesia Gemilang?

4. Apakah kompetensi, disiplin kerja, dan kompensasi secara simultan berpengaruh signifikan terhadap kinerja karyawan pada PT. Moranthel Indonesia Gemilang ? 


\section{TEORI}

\section{A. Kompetensi}

Ada suatu pendekatan yang dapat digunakan untuk memahami kesuksesan dari kompetensi, dengan meningkatan pengetahuan kerja. Kompetensi karyawan dalam suatu perusahaan berperan penting dalam kemajuan perusahaan untuk mengelola sumber daya-sumber daya yang ada dalam peruahaan.Karyawan yang berkompeten sangat diharapkan karyawan dalam menunjang aktifitas bekerja. Kompetensi dalam organisasi sangat diperlukan untuk mengembangkan lingkungan kerja yang kondusif dan membangun iklim motivasi bagi karyawan sehingga diharapkan akan menghasilkan kinerja tinggi.

Menurut Spencer and Spencer (1993:9), dikutip oleh Wibowo (2016:272) bahwa kompetensi merupakan landasan dan karakteristik orang dan mengindikasikan cara berperilaku atau berpikir, menyamakan situasi, dan mendukung untuk periode waktu yang cukup lama. Sedangkan menurut Hutapea dan Thoha (2008:28) mengungkapkan bahwa ada tiga komponen utama pembentukan kompetensi yaitu pengetahuan yang dimiliki seseorang, kemampuan, dan prilaku individu.

Harris dikutip oleh Tjutju Yuniarsih dan Suwatno (2008:23) menyatakan bahwa "Competencies are underlying bodies of knowledge, abilities, experience, and other requirements necessary to succesfully perform the job. Artinya kompetensi merupakan pengetahuan dasar yang pokok, kemampuan,pengalaman, dan persyaratan yang diperlukan untuk melakukan pekerjaan dengan sukses

\section{B. Disiplin Kerja}

Kedisipilinan kerja karyawan yang baik merupakan refleksi dari rasa tanggung jawab yang baik untuk dapat menyelesaikan tugas-tugas yang diberikan oleh perusahaan.

Menurut Hasibuan (2013:193) disiplin yang baik mencerminkan besarnya rasa tanggung jawab seseorang terhadap tugas-tugas yang diberikan kepadanya. Hal ini mendorong gairah kerja, semangat kerja, dan terwujudnya kinerja. Oleh karena itu, setiap atasan selalu berusaha agar para bawahannya mempunyai displin yang baik. Seseorang atasan dikatakan efektif dalam kepemimpian, jika para bawahannya berdisiplin baik. Untuk memelihara dan meningkatkan kedisiplinan yang baik adalah menetapkan peraturan dan tata tertib kerja yang mengikat, memenuhi keinginan dan kebutuhan karyawannya, menentukan garis wewenang dan tanggung jawab yang tegas dan jelas, membentuk hubungan kerja yang harmonis, dan membuat suasana kondisi kerja yang baik

Menurut Siagian (2008:13) menegaskan bahwa daya pendorong yang megakibatkan seseorang anggota organisasi mau dan rela untuk mengerahkan kemapuan, peranan dalam membentuk keahlian dan keterampilan, tenaga dan waktu untuk menyelenggarakan berbagai kegiatan yang menjadi tanggung jawab dan menunaikan kewajibannya dalam rangka pencapaian tujuan organisasi.

\section{Kompensasi}

Kompensasi merupakan pemberian upah sebagai imbalan baik berupa uang dan bukan uang. Pembayaran upah biasanya dalam bentuk konsep pembayaran 
yang berati luas dari pada merupakan ide gaji secara normal berupa keuangan tetapi tidak suatu dimensi yang non financial.

Menurut Henry Simamora (2014:506) kompensasi adalah semua bentuk kembalian finansial, jasa-jasa terwujud dan tunjangan yang diperoleh karyawan sebagai bagian dari hubungan kekaryawanan.

Menurut Mangkunegara (2013:83) Kompensasi merupakan sesuatu yang dipertimbangkan sebagai sesuatu yang sebanding dan kompensasi yang diberikan kepada pegawai sebagai penghargaan dari pelayanan mereka.

Menurut Hadari Nawawi $(2011 ; 315)$ mengemukan bahwa kompensasi organisasi/perusahaan berarti penghargaan/ganjaran pada para pekerja yang telah memberikan kontribusi dalam mewujudkan tujuannya melalui kegiatan yang disebut bekerja.

\section{Kinerja}

Kinerja bersumber dari bahasa Inggris yaitu performance. Banyak juga pendapat yang berpandangan bahwa performance merupakan wujud hasil kerja atau prestasikerja. Tetapi kinerja memiliki arti yang lebih mencakup secara luas,bukan hanya sekedar ouput kerja, tetapi termasuk bagian dari proses pekerjaan (dari awal sampai akhir). Keberhasilan organisasi dalam memperbaiki kinerja organisasinya sangat bergantung pada kualitas SDM yang bersangkutan dalam berkarya atau bekerja sehingga organisasi perlu memiliki pegawai yang berkemampuan dan berkinerja tinggi.

Menurut Mangkunegara (2013:9) Kinerja adalah hasil kerja secara kualitas dan kuantitas yang dicapai oleh seorang pegawai dalam melaksanakan tugasnya sesuai dengan tanggung jawab yang diberikan kepadanya.

Menurut Hasibuan (2013:94) kinerja adalah suatu hasil kerja yang di capai seseorang dalam melaksanakan tugas-tugas yang dibebankan kepadanya yang didasarkan atas kecakapan, pengalaman, dan kesungguhan serta waktu.

Definisi Kinerja menurut Arif Ramdhani (2011:18) kinerja adalah kesediaan seseorang atau kelompok orang untuk melakukan kegiatan dan menyempurnakannya sesuai dengan tanggung jawabnya dengan hasil seperti yang diharapkan.Kinerja merupakan performance atau unjuk kerja.

\section{METODOLOGI PENELITIAN}

\section{A. Metode Penelitian}

Dalam desain penelitian ini, penulis menggunakan pengujian Analis regresi berganda dan pengujian asumsi klasik dengan bantuan Software SPSS 24. Sifat penelitian yang dilakukan oleh peneliti bersifat deskriptif kuantitatif.Adapun pengertian mengenai metode deskriptif menurut Syofian Siregar (2014:15) penelitian deskriptif adalah penelitian yang dilakukan untuk mengetahui nilai variabel mandiri, baik satu variabel atau lebih (independent) tanpa membuat perbandingan atau penghubungan dengan variabel lain.

Dalam penelitian ini peneliti menggunakan skala likert dalam pengukuran hasil jawaban instrument kuesioner. Skala likert dalam penelitian ini peneliti bagi menjadi lima alternatif jawaban dengan pemberian bobot nilai. 


\section{B. Populasi Dan Sampel}

Populasi dalam penelitian ini adalah karyawan yang bekerja pada PT Moranthel Indonesia Gemilang yang berjumlah 108 karyawan. Adapun sampel diambil dengan pertimbangan khusus/kriteria atau ciri-ciri khusus yang memiliki hubungan yang erat dengan kriteria atau ciri-ciri populasi.

\section{HASIL PENELITIAN DAN PEMBAHASAN}

\section{A. Hasil Penelitian}

\section{Analisa Deskriptif}

Rentang skala rata-rata skor instrument dapat dihitung dengan cara :

$$
\text { Rentang Skala }=\frac{\text { SkorTerbesar }- \text { SkorTerkecil }}{\text { SkorTerbesar }}
$$

\section{a. Analisa Deskriptif Kompetensi $\left(X_{1}\right)$}

Hasil Distribusi jawaban instrument kompetensi $\left(X_{1}\right)$ dapat disajikan seperti pada tabel di bawah ini :

Tabel 4.1 : Distribusi Jawaban Instrument Kompetensi $\left(X_{1}\right)$

\begin{tabular}{|c|c|c|c|c|c|c|c|c|c|c|}
\hline \multirow{3}{*}{ No } & Kompetensi (X1) & \multicolumn{5}{|c|}{ Tanggapan } & \multirow{3}{*}{$\begin{array}{l}\text { Skor } \\
\sum \mathbf{X}_{1 \mathrm{t}}\end{array}$} & \multirow{3}{*}{$\mathbf{n}$} & \multirow{3}{*}{$\begin{array}{l}\text { Rata- } \\
\text { Rata }\end{array}$} & \multirow{3}{*}{$\begin{array}{l}\text { Kate } \\
\text { Gori }\end{array}$} \\
\hline & \multirow{2}{*}{ Pernyataan } & 5 & 4 & 3 & 2 & 1 & & & & \\
\hline & & SS & $\mathbf{S}$ & RR & TS & STS & & & & \\
\hline & $\begin{array}{l}\text { Pengetahuan } \\
\text { (knowledge) }\end{array}$ & & & & & & & & & \\
\hline 1 & $\begin{array}{l}\text { Saya kurang memiliki } \\
\text { pengetahuan sesuai } \\
\text { dengan bidang kerja }\end{array}$ & 38 & 41 & 17 & 12 & 0 & 429 & 108 & 3.97 & B \\
\hline 2 & $\begin{array}{l}\text { Perusahaan merekrut } \\
\text { karyawan sesuai dgn } \\
\text { pengetahuan kerjaan }\end{array}$ & 37 & 37 & 28 & 6 & 0 & 429 & 108 & 3.97 & B \\
\hline & $\begin{array}{l}\text { Pemahaman } \\
\text { (understanding) }\end{array}$ & & & & & & & & & \\
\hline 3 & $\begin{array}{l}\text { Rekan kerja kurang } \\
\text { mampu memberikan } \\
\text { pemahaman kerja } \\
\text { kpd karyawan lainnya }\end{array}$ & 39 & 47 & 19 & 3 & 0 & 446 & 108 & 4.13 & B \\
\hline 4 & $\begin{array}{l}\text { Kondisi dan keadaan } \\
\text { perusahaan saat ini } \\
\text { sudah sesuai dengan } \\
\text { harapan karyawan }\end{array}$ & 32 & 55 & 16 & 5 & 0 & 438 & 108 & 4.06 & B \\
\hline & Kemampuan (skill) & & & & & & & & & \\
\hline 5 & $\begin{array}{l}\text { Karyawan mampu } \\
\text { dalam menggunakan } \\
\text { fasilitas perusahaan } \\
\text { dengan baik dalam } \\
\text { memperlancar hasil } \\
\text { kerja }\end{array}$ & 30 & 53 & 21 & 4 & 0 & 433 & 108 & 4.01 & B \\
\hline 6 & $\begin{array}{lr}\text { Saya } & \text { memiliki } \\
\text { spesialis } & \text { keahlian } \\
\text { tertentu yang sesuai } & \text { sengan bidang } \\
\text { denan } & \text { pekerjaan yang saya } \\
\text { geluti } & \end{array}$ & 31 & 60 & 15 & 2 & 0 & 444 & 108 & 4.11 & B \\
\hline
\end{tabular}




\begin{tabular}{|c|c|c|c|c|c|c|c|c|c|c|}
\hline \multirow{3}{*}{ No } & Kompetensi (X1) & \multicolumn{5}{|c|}{ Tanggapan } & \multirow{3}{*}{$\begin{array}{l}\text { Skor } \\
\sum \mathbf{X}_{1 \mathrm{1t}}\end{array}$} & \multirow{3}{*}{$\mathbf{n}$} & \multirow{3}{*}{$\begin{array}{l}\text { Rata- } \\
\text { Rata }\end{array}$} & \multirow{3}{*}{$\begin{array}{l}\text { Kate } \\
\text { Gori }\end{array}$} \\
\hline & \multirow{2}{*}{ Pernyataan } & 5 & 4 & 3 & 2 & 1 & & & & \\
\hline & & SS & $\mathbf{S}$ & $\mathbf{R R}$ & TS & STS & & & & \\
\hline & Nilai (value) & & & & & & & & & \\
\hline 7 & 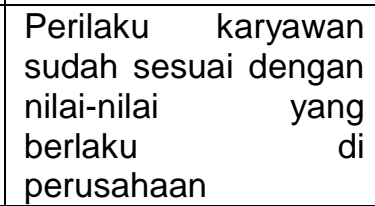 & 34 & 54 & 15 & 5 & 0 & 441 & 108 & 4.08 & B \\
\hline \multirow[t]{2}{*}{8} & \begin{tabular}{|lr|} 
Terkadang & karyawan \\
kurang & memiiki \\
kejujuran dan dalam & melaksanakan tugas \\
\multicolumn{2}{l}{ dan kewajibannya }
\end{tabular} & 26 & 60 & 15 & 7 & 0 & 429 & 108 & 3.97 & B \\
\hline & Sikap (attitude) & & & & & & & & & \\
\hline \multirow[t]{2}{*}{9} & \begin{tabular}{|lrr}
\multicolumn{2}{|l}{ Pimpinan } & memiliki \\
sikap yang baik \\
kepada & karyawan \\
lainnya & \\
\end{tabular} & 41 & 48 & 14 & 5 & 0 & 449 & 108 & 4.16 & $B$ \\
\hline & Minat (interest) & & & & & & & & & \\
\hline \multirow[t]{3}{*}{10} & $\begin{array}{l}\text { Saya kurang berminat } \\
\text { dalam melanjutkan } \\
\text { pendidikan yang lebih } \\
\text { tinggi } \\
\end{array}$ & 36 & 43 & 16 & 12 & 1 & 425 & 108 & 3.94 & B \\
\hline & Jumlah & 344 & 498 & 176 & 61 & 1 & 4363 & 1080 & 40.40 & \\
\hline & & 31.85 & 46.11 & $16.30^{\circ}$ & $5.65^{\circ}$ & $0.09 \%$ & & & $3.74 \%$ & \\
\hline
\end{tabular}

Sumber : Data Olahan Kuesioner 2018

\section{b. Analisa Deskriptif Disiplin Kerja $\left(\mathrm{X}_{2}\right)$}

Hasil Distribusi jawaban instrument disiplin kerja $\left(\mathrm{X}_{2}\right)$ dapat disajikan seperti pada tabel di bawah ini :

Tabel 4.2 : Distribusi Jawaban Instrument Disiplin Kerja $\left(X_{2}\right)$

\begin{tabular}{|c|c|c|c|c|c|c|c|c|c|c|}
\hline \multirow{3}{*}{ No } & Disiplin Kerja & \multicolumn{5}{|c|}{ Tanggapan } & \multirow{3}{*}{$\mathbf{N}$} & \multirow{3}{*}{$\begin{array}{l}\text { Skor } \\
\sum X_{2}\end{array}$} & \multirow{3}{*}{$\begin{array}{l}\text { Rata- } \\
\text { Rata }\end{array}$} & \multirow{3}{*}{$\begin{array}{l}\text { Kate } \\
\text { gori }\end{array}$} \\
\hline & \multirow{2}{*}{ Pernyataan } & 5 & & 3 & 2 & 1 & & & & \\
\hline & & SS & 5 & RR & TS & STS & & & & \\
\hline & Frekuensi Kehadiran & & & & & & & & & \\
\hline 1 & $\begin{array}{l}\text { Tingkat kehadiran } \\
\text { karyawan belum } \\
\text { mampu meningkatkan } \\
\text { produktifitaskerja } \\
\text { karyawan }\end{array}$ & 34 & 48 & 18 & 7 & 1 & 108 & 431 & 3.99 & B \\
\hline 2 & $\begin{array}{l}\text { Karyawan hadir dan } \\
\text { pulang tepat waktu } \\
\text { sesuai dengan waktu } \\
\text { yang telah ditentukan } \\
\text { perusahaan }\end{array}$ & 27 & 56 & 19 & 6 & 0 & 108 & 428 & 3.96 & B \\
\hline & $\begin{array}{l}\text { Tingkat } \\
\text { Kewaspadaan }\end{array}$ & & & & & & & & & \\
\hline 3 & $\begin{array}{lr}\text { Karyawan } & \text { kurang } \\
\text { waspada } & \text { dalam } \\
\text { melaksanakan } & \text { tugas } \\
\text { vang diberikan } & \end{array}$ & 31 & 48 & 19 & 9 & 1 & 108 & 423 & 3.92 & B \\
\hline
\end{tabular}




\begin{tabular}{|c|c|c|c|c|c|c|c|c|c|c|}
\hline \multirow[b]{2}{*}{ No } & Disiplin Kerja & \multicolumn{5}{|c|}{ Tanggapan } & \multirow[b]{2}{*}{$\mathbf{N}$} & \multirow{2}{*}{$\begin{array}{l}\text { Skor } \\
\sum \mathrm{X}_{2}\end{array}$} & \multirow{2}{*}{$\begin{array}{l}\text { Rata- } \\
\text { Rata }\end{array}$} & \multirow{2}{*}{ Kate } \\
\hline & Pernyataan & 5 & 4 & 3 & 2 & 1 & & & & \\
\hline 4 & $\begin{array}{|lr|}\text { Pengawasan } & \text { yang } \\
\text { dilakukan pimpinan } \\
\text { saat ini efektif dan } \\
\text { efisien } & \text { dalam } \\
\text { memperbaiki perilaku } \\
\text { kerja karyawan }\end{array}$ & 25 & 51 & 26 & 6 & 0 & 108 & 419 & 3.88 & B \\
\hline & \begin{tabular}{|l|} 
Ketaatan Pada \\
Standar Kerja \\
\end{tabular} & & & & & & & & & \\
\hline 5 & $\begin{array}{l}\text { Karyawan taat dan } \\
\text { mematuhi standar kerja } \\
\text { yang berlaku di } \\
\text { perusahaan }\end{array}$ & 18 & 55 & 26 & 9 & 0 & 108 & 406 & 3.76 & B \\
\hline 6 & $\begin{array}{ll}\text { Karyawan } & \text { bekerja } \\
\text { sesuai dengan standar } \\
\begin{array}{l}\text { operasional prosedur } \\
\text { yang berlaku }\end{array}\end{array}$ & 16 & 63 & 21 & 7 & 1 & 108 & 410 & 3.80 & B \\
\hline & \begin{tabular}{|l|} 
Ketaatan Pada \\
Peraturan Kerja \\
\end{tabular} & & & & & & & & & \\
\hline 7 & \begin{tabular}{|lr} 
Sangsi & yang \\
mampu diberikan \\
efek memberikan \\
karyawan & \\
\end{tabular} & 18 & 65 & 19 & 6 & 0 & 108 & 419 & 3.88 & B \\
\hline 8 & $\begin{array}{l}\text { Karyawan kurang taat } \\
\text { dan patuh terhadap } \\
\text { peraturan yang berlaku }\end{array}$ & 19 & 64 & 18 & 7 & 0 & 108 & 419 & 3.88 & B \\
\hline & Etika Kerja & & & & & & & & & \\
\hline 9 & $\begin{array}{l}\text { Karyawan memiliki } \\
\text { etika dalam komunikasi } \\
\text { kesesama rekan kerja }\end{array}$ & 25 & 66 & 15 & 2 & 0 & 108 & 438 & 4.06 & B \\
\hline 10 & \begin{tabular}{|lr} 
Saling & menghormati, \\
bila & bertemu \\
dilingkungan pekerjaan
\end{tabular} & 27 & 62 & 14 & 5 & 0 & 108 & 435 & 4.03 & B \\
\hline & Jumlah & 240 & 578 & 195 & 64 & 3 & 1080 & 4228 & 39.15 & \\
\hline & & $22.22 \%$ & $53.52 \%$ & $18.06 \%$ & $5.93 \%$ & $0.28 \%$ & & & 3.91 & \\
\hline
\end{tabular}

Sumber : Data Olahan Kuesioner 2018

\section{c. Analisa Deskriptif Kompensasi $\left(X_{3}\right)$}

Hasil penyebaran instrument kepada 108 karyawan yang bekerja selanjutnya dapat disajikan seperti pada tabel di bawah ini :

Tabel 4.3 : Analisa Deskriptif Kompensasi $\left(\mathrm{X}_{3}\right)$

\begin{tabular}{|c|c|c|c|c|c|c|c|c|c|c|}
\hline \multirow{3}{*}{ No } & \multirow{3}{*}{$\begin{array}{c}\text { Kompensasi } \\
\text { Pernyataan }\end{array}$} & \multicolumn{5}{|c|}{ Tanggapan } & \multirow{3}{*}{$\begin{array}{l}\text { Skor } \\
\sum X_{3}\end{array}$} & \multirow{3}{*}{$\mathbf{N}$} & \multirow{3}{*}{$\begin{array}{l}\text { Rata } \\
\text { Rata }\end{array}$} & \multirow{3}{*}{$\begin{array}{l}\text { Kate } \\
\text { gori }\end{array}$} \\
\hline & & 5 & 4 & 3 & 2 & 1 & & & & \\
\hline & & SS & $\mathbf{S}$ & RR & TS & STB & & & & \\
\hline & Upah dan gaji & & & & & & & & & \\
\hline 1 & $\begin{array}{lrr}\text { Gaji yang } & \text { diterima } & \text { sudah } \\
\text { memenuhi } & \text { kebutuhan } & \text { hidup } \\
\text { sehari-hari } & \text { karyawan } & \text { dan } \\
\text { keluarganya } & & \end{array}$ & 21 & 44 & 27 & 13 & 3 & 391 & 108 & 3.62 & B \\
\hline
\end{tabular}




\begin{tabular}{|c|c|c|c|c|c|c|c|c|c|c|}
\hline \multirow{3}{*}{ No } & Kompensasi & \multicolumn{5}{|c|}{ Tanggapan } & \multirow{3}{*}{$\begin{array}{l}\text { Skor } \\
\sum \mathrm{X}_{3}\end{array}$} & \multirow{3}{*}{$\mathbf{N}$} & \multirow{3}{*}{$\begin{array}{l}\text { Rata } \\
- \\
\text { Rata }\end{array}$} & \multirow{3}{*}{$\begin{array}{l}\text { Kate } \\
\text { gori }\end{array}$} \\
\hline & \multirow{2}{*}{ Pernyataan } & 5 & 4 & 3 & 2 & 1 & & & & \\
\hline & & SS & $\mathbf{S}$ & RR & TS & STB & & & & \\
\hline \multirow[t]{2}{*}{2} & $\begin{array}{l}\text { Kenaikan gaji setiap tahunnya } \\
\text { sudah sesuai dengan harapan }\end{array}$ & 27 & 47 & 23 & 11 & 0 & 414 & 108 & 3.83 & B \\
\hline & Insentif & & & & & & & & & \\
\hline 3 & $\begin{array}{|lr|}\begin{array}{l}\text { Pemberian insentif } \\
\text { meningkatkan }\end{array} & \text { belum } \\
\text { karyawan } & \text { kinerja } \\
\end{array}$ & 26 & 61 & 15 & 6 & 0 & 431 & 108 & 3.99 & B \\
\hline \multirow[t]{2}{*}{4} & $\begin{array}{l}\text { Bonus yang saya terima saat } \\
\text { ini sudah sesuai dengan } \\
\text { prestasi kerja saya }\end{array}$ & 24 & 59 & 19 & 6 & 0 & 425 & 108 & 3.94 & B \\
\hline & Tunjangan & & & & & & & & & \\
\hline 5 & $\begin{array}{l}\text { Pemberian tunjangan pensiun } \\
\text { bagi karyawan dapat } \\
\text { memberikan kesejahteraan } \\
\text { karyawan }\end{array}$ & 22 & 63 & 19 & 4 & 0 & 427 & 108 & 3.95 & B \\
\hline 6 & \begin{tabular}{|l} 
Tunjangan pensiun dan \\
pesangon yang ada saat ini \\
sudah sesuai dengan \\
peraturan perundang- \\
undangan yang berlaku
\end{tabular} & 30 & 51 & 23 & 4 & 0 & 431 & 108 & 3.99 & B \\
\hline \multirow[t]{2}{*}{7} & $\begin{array}{llr}\text { Kebijakan perusahaan dalam } \\
\text { memberikan } & \text { asuransi } \\
\text { kesehatan } & \text { (BPJS) } & \text { sudah } \\
\text { meringankan } & \text { biaya } \\
\text { pengobatan } & \text { karyawan dan } \\
\text { keluarga } & & \\
\end{array}$ & 28 & 50 & 25 & 5 & 0 & 425 & 108 & 3.94 & B \\
\hline & Fasilitas & & & & & & & & & \\
\hline 8 & $\begin{array}{l}\text { Sarana dan prasarana yang } \\
\text { diberikan perusahaan dalam } \\
\text { menunjang aktifitas kerja } \\
\text { karyawan saat ini membantu } \\
\text { karyawan dalam } \\
\text { melaksanakan pekerjaaan } \\
\end{array}$ & 29 & 61 & 11 & 6 & 1 & 435 & 108 & 4.03 & $B$ \\
\hline 9 & $\begin{array}{l}\text { Fasilitas ruangan tempat } \\
\text { ibadah dan ruang pantry } \\
\text { sudah nyaman bagi karyawan }\end{array}$ & 33 & 53 & 19 & 3 & 0 & 440 & 108 & 4.07 & B \\
\hline 10 & $\begin{array}{lcc}\text { Karyawan } & \text { kurang } & \text { merasa } \\
\text { nyaman dengan } & \text { kondisi } \\
\text { lingkungan kerja saat ini }\end{array}$ & 43 & 45 & 15 & 5 & 0 & 450 & 108 & 4.17 & B \\
\hline & Jumlah & 283 & 534 & 196 & 63 & 4 & 4269 & 1080 & 39.53 & \\
\hline
\end{tabular}

Sumber : Data Olahan Kuesioner 2018

\section{d. Analisa Deskriptif Kinerja (Y)}

Hasil Distribusi jawaban instrument Kinerja $(Y)$ dapat disajikan seperti pada tabel di bawah ini : 
Tabel 4.4 : Distribusi Jawaban Instrument Kinerja $(Y)$

\begin{tabular}{|c|c|c|c|c|c|c|c|c|c|c|}
\hline \multirow[b]{2}{*}{ No } & Kinerja & \multicolumn{5}{|c|}{ Tanggapan } & \multirow{2}{*}{$\begin{array}{l}\text { Skor } \\
\sum Y \mathrm{Yt}\end{array}$} & \multirow[b]{2}{*}{$\mathbf{N}$} & \multirow{2}{*}{$\begin{array}{l}\text { Rata- } \\
\text { Rat }\end{array}$} & \multirow{2}{*}{$\begin{array}{l}\text { Kate } \\
\text { gori }\end{array}$} \\
\hline & Pernyataan & \begin{tabular}{|l|}
5 \\
SS \\
\end{tabular} & \begin{tabular}{|l|}
4 \\
$S$ \\
\end{tabular} & \begin{tabular}{|l|}
3 \\
$R R$
\end{tabular} & \begin{tabular}{|l|} 
a2 \\
TS
\end{tabular} & \begin{tabular}{|l} 
\\
STS
\end{tabular} & & & & \\
\hline & Jumlah Pekerjaan & & & & & & & & & \\
\hline 1 & $\begin{array}{l}\text { Hasil kerja karyawan } \\
\text { sesuai kemampuan } \\
\text { karyawan }\end{array}$ & 38 & 46 & 17 & 7 & 0 & 439 & 108 & 4.06 & B \\
\hline 2 & $\begin{array}{lr}\text { Secara } & \text { kuantitas } \\
\text { karyawan } & \text { tidak } \\
\text { dapat menyelesaikan } \\
\text { pekerjaan } & \text { tepat } \\
\text { waktu } & \\
\end{array}$ & 35 & 46 & 20 & 7 & 0 & 433 & 108 & 4.01 & B \\
\hline & Kualitas Pekerjaan & & & & & & & & & \\
\hline 3 & $\begin{array}{l}\text { Karyawan kurang } \\
\text { memiliki } \\
\text { keterampilan dalam } \\
\text { memberikan } \\
\text { pengajaran kepada } \\
\text { karyawan lainnya }\end{array}$ & 34 & 53 & 14 & 6 & 1 & 437 & 108 & 4.05 & B \\
\hline 4 & $\begin{array}{l}\text { Karyawan memiliki } \\
\text { keterampilan dan } \\
\text { ketelitian dalam } \\
\text { bekerja }\end{array}$ & 32 & 55 & 16 & 5 & 0 & 438 & 108 & 4.06 & B \\
\hline & Ketepatan Waktu & & & & & & & & & \\
\hline 5 & $\begin{array}{l}\text { Karyawan dapat } \\
\text { menyelesaikan } \\
\text { pekerjan sesuai } \\
\text { dengan waktuyang } \\
\text { telah ditetapkan } \\
\text { perusahaan }\end{array}$ & 33 & 52 & 19 & 3 & 1 & 437 & 108 & 4.05 & B \\
\hline 6 & $\begin{array}{lr}\text { Pesanan } & \text { dan } \\
\text { pengiriman } & \text { klien } \\
\text { sesuai dengan } \\
\text { tenggat waktu yang } \\
\text { telah ditentukan }\end{array}$ & 31 & 53 & 19 & 4 & 1 & 433 & 108 & 4.01 & B \\
\hline & Kehadiran & & & & & & & & & \\
\hline 7 & $\begin{array}{lrr}\begin{array}{l}\text { Karyawan } \\
\text { berada } \\
\text { kerjanya }\end{array} & \text { di } & \text { selalu } \\
\end{array}$ & 28 & 54 & 22 & 4 & 0 & 430 & 108 & 3.98 & B \\
\hline 8 & $\begin{array}{l}\text { Kurang memiliki } \\
\text { inisiatif dalam } \\
\text { meningkatkan } \\
\text { kehadiran setiap } \\
\text { harinya }\end{array}$ & 30 & 56 & 19 & 3 & 0 & 437 & 108 & 4.05 & B \\
\hline & $\begin{array}{l}\text { Kemampuan } \\
\text { bekerja sama }\end{array}$ & & & & & & & & & \\
\hline 9 & $\begin{array}{lr}\text { Mampu } & \text { bekerja } \\
\text { sama } & \text { dalam } \\
\text { keadaan apapun }\end{array}$ & 33 & 53 & 15 & 6 & 1 & 435 & 108 & 4.03 & B \\
\hline 10 & Tanpa di minta & 25 & 56 & 18 & 8 & 1 & 420 & 108 & 3.89 & $B$ \\
\hline
\end{tabular}




\begin{tabular}{|l|l|l|l|l|l|l|l|l|l|}
\hline $\begin{array}{l}\text { karyawan membantu } \\
\text { karyawan lain dalam } \\
\text { pelaksanan } \\
\text { pekerjaan }\end{array}$ & & & & & & & & & \\
\hline Jumlah & $\mathbf{3 1 9}$ & $\mathbf{5 2 4}$ & $\mathbf{1 7 9}$ & $\mathbf{5 3}$ & $\mathbf{5}$ & $\mathbf{4 3 3 9}$ & $\mathbf{1 0 8 0}$ & $\mathbf{4 0 . 1 8}$ & \\
\hline
\end{tabular}

Sumber : Data Olahan Kuesioner 2018

\section{Uji Kualitas Data}

a. Uji Validitas Instrumen

Hasil pengujian tingkat validitas dari setiap butir pertanyaan yang dihitung dengan menggunakan SPSS (Statistical Packed For Social Science), disajikan dalam tabel berikut :

Tabel 4.5 : Hasil Uji Validitas Kompetensi $\left(X_{1}\right)$

\begin{tabular}{|l|c|c|c|}
\hline No & $\mathrm{r}_{\text {hitung }}$ & $\mathrm{r}_{\text {table }}$ & Keterangan \\
\hline 1 & 0.548 & 0.189 & Valid \\
\hline 2 & 0.572 & 0.189 & Valid \\
\hline 3 & 0.643 & 0.189 & Valid \\
\hline 4 & 0.582 & 0.189 & Valid \\
\hline 5 & 0.657 & 0.189 & Valid \\
\hline 6 & 0.533 & 0.189 & Valid \\
\hline 7 & 0.426 & 0.189 & Valid \\
\hline 8 & 0.594 & 0.189 & Valid \\
\hline 9 & 0.537 & 0.189 & Valid \\
\hline 10 & 0.385 & 0.189 & Valid \\
\hline
\end{tabular}

Sumber : Data Olahan Kuesioner 2018

Tabel 4.6 : Hasil Uji Validitas Disiplin Kerja $\left(\mathrm{X}_{2}\right)$

\begin{tabular}{|c|c|c|c|}
\hline No & $\mathrm{r}_{\text {hitung }}$ & $\mathrm{r}_{\text {table }}$ & Keterangan \\
\hline 1 & 0.590 & 0.189 & Valid \\
\hline 2 & 0.636 & 0.189 & Valid \\
\hline 3 & 0.678 & 0.189 & Valid \\
\hline 4 & 0.690 & 0.189 & Valid \\
\hline 5 & 0.679 & 0.189 & Valid \\
\hline 6 & 0.541 & 0.189 & Valid \\
\hline 7 & 0.615 & 0.189 & Valid \\
\hline 8 & 0.509 & 0.189 & Valid \\
\hline 9 & 0.627 & 0.189 & Valid \\
\hline 10 & 0.541 & 0.189 & Valid \\
\hline
\end{tabular}

Sumber : Data Olahan Kuesioner 2018

Tabel 4.7 : Hasil Uji Validitas Kompensasi $\left(\mathrm{X}_{3}\right)$

\begin{tabular}{|l|c|c|c|}
\hline No & $\mathrm{r}_{\text {hitung }}$ & $\mathrm{r}_{\text {table }}$ & Keterangan \\
\hline 1 & 0.631 & 0.189 & Valid \\
\hline 2 & 0.651 & 0.189 & Valid \\
\hline 3 & 0.649 & 0.189 & Valid \\
\hline 4 & 0.642 & 0.189 & Valid \\
\hline 5 & 0.555 & 0.189 & Valid \\
\hline 6 & 0.650 & 0.189 & Valid \\
\hline 7 & 0.689 & 0.189 & Valid \\
\hline 8 & 0.595 & 0.189 & Valid \\
\hline
\end{tabular}




\begin{tabular}{|l|c|c|c|}
\hline 9 & 0.628 & 0.189 & Valid \\
\hline 10 & 0.613 & 0.189 & Valid \\
\hline \multicolumn{4}{|c|}{ Sumber : Data Olahan Kuesioner 2018 }
\end{tabular}

Tabel 4.8 : Hasil Uji Validitas Kinerja (Y)

\begin{tabular}{|l|c|c|c|}
\hline No & $\mathrm{r}_{\text {hitung }}$ & $\mathrm{r}_{\text {table }}$ & Keterangan \\
\hline 1 & 0.626 & 0.189 & Valid \\
\hline 2 & 0.632 & 0.189 & Valid \\
\hline 3 & 0.766 & 0.189 & Valid \\
\hline 4 & 0.680 & 0.189 & Valid \\
\hline 5 & 0.807 & 0.189 & Valid \\
\hline 6 & 0.709 & 0.189 & Valid \\
\hline 7 & 0.770 & 0.189 & Valid \\
\hline 8 & 0.694 & 0.189 & Valid \\
\hline 9 & 0.705 & 0.189 & Valid \\
\hline 10 & 0.504 & 0.189 & Valid \\
\hline
\end{tabular}

Sumber : Data Olahan Kuesioner 2018

\section{b. Uji Reliabilitas}

Teknik yang digunakan untuk uji reliabilitas ini adalah teknik Alpha Cronbach, dimana suatu instrument dapat dikatakan handal (reliabel) bila Instrumen memiliki tingkat reliabilitas yang tinggi jika nilai koefisien yang diperoleh $>0,60$. Dari pengujian reliabilitas ini dapat diketahui bahwa variabel-variabel Kompetensi $\left(\mathrm{X}_{1}\right)$, Disiplin Kerja $\left(\mathrm{X}_{2}\right)$, Kompensasi $\left(\mathrm{X}_{3}\right)$ sebagai variabel independen dan Kinerja $(\mathrm{Y})$ sebagai variabel dependen seluruhnya dinyatakan reliable karena nilai Alpha Cronbach masingmasing variabel melebihi angka 0,6. Untuk mengetahui secara jelas reliabilitas variabel dependent dan variabel independent dapat dilihat pada Tabel 4.9

Tabel 4.9 : Hasil Uji Reliabilitas

\begin{tabular}{|l|c|c|}
\hline \multicolumn{1}{|c|}{ Variabel } & Alpha Cronbach & Keterangan \\
\hline Kompetensi $\left(\mathrm{X}_{1}\right)$ & 0,731 & Reliabel \\
\hline Disiplin Kerja $\left(\mathrm{X}_{2}\right)$ & 0,812 & Reliabel \\
\hline Kompensasi $\left(\mathrm{X}_{3}\right)$ & 0,830 & Reliabel \\
\hline Kinerja $(\mathrm{Y})$ & 0,875 & Reliabel \\
\hline
\end{tabular}

\section{Uji Hipotesis}

Hipotesis adalah jawaban sementara terhadap rumusan masalah penelitian.

Dikatakan sementara karena jawaban yang diberikan baru didasarkan teori relevan, belum didasarkan pada fakta-fakta empiris yang diperoleh melalui pengumpulan data. Oleh karena itu rumusan masalah penelitian biasanya disusun dalam bentuk kalimat pernyataan. Dalam penelitian ini, hipotesis akan diuji secara parsial maupun simultan.

\section{a. Uji t Parsial}

Uji statistik t pada dasarnya menunjukkan seberapa jauh pengaruh satu variabel independen secara individual dalam menerangkan variabel dependen. Pengujian dilakukan dengan menggunakan signifikan level 0,05 ( $\alpha=5 \%)$. 
Pengujian dilakukan melalui uji $t$ dengan membandingkan $t_{\text {hitung }}$ dengan $t_{\text {tabel }}$ pada $\alpha$ 0,05 . Apabila hasil perhitungan menunjukkan:

a. $t_{\text {hitung }}>t_{\text {tabel }} 1,983$ maka Ho ditolak dan Ha diterima (Signifikan)

b. $\quad t_{\text {hitung }} \leq t_{\text {tabel }} 1,983$ maka Ho diterima dan Ha ditolak (Tidak Signifikan)

Pengujian hipotesis secara parsial dapat disajikan seperti di bawah ini :

1) Uji Hipotesis Parsial Kompetensi $\left(X_{1}\right)$ Terhadap Kinerja $(Y)$

Tabel 4.10 : Hasil Output Uji Parsial Kompetensi $\left(X_{1}\right)$ Terhadap Kinerja (Y)

\begin{tabular}{|c|c|c|c|c|c|c|}
\hline & & $\begin{array}{l}\text { Unstandardized } \\
\text { B }\end{array}$ & $\begin{array}{l}\text { Coefficients } \\
\text { Std. Error }\end{array}$ & $\begin{array}{l}\text { Standardized } \\
\text { Coefficients } \\
\text { Beta }\end{array}$ & $\mathrm{T}$ & Sig. \\
\hline \multirow[t]{2}{*}{1} & (Constant) & 24,513 & 4,726 & & 5,187 &, 000 \\
\hline & Kompetensi (X1) & ,388 & , 116 & ,308 & 3,335 & 001 \\
\hline
\end{tabular}

a. Dependent Variable: Kinerja $(\mathrm{Y})$

Melihat tabel di atas menunjukkan bahwa $t_{\text {hitung }} 3,335>1,983$ dan nilai Sig $0,001<0,05$ maka $\mathrm{H}_{01}$ ditolak dan $\mathrm{H}_{\mathrm{a} 1}$ diterima (Signifikan) artinya terdapat pengaruh positif dan signifikan antara kompetensi $\left(\mathrm{X}_{1}\right)$ terhadap kinerja karyawan $(\mathrm{Y})$.

\section{2) Uji Hipotesis Parsial Disiplin Kerja $\left(X_{2}\right)$ Terhadap Kinerja ( $Y$ )}

Tabel 4.11 : Hasil Uji Parsial Disiplin Kerja $\left(\mathrm{X}_{2}\right)$ Terhadap Kinerja (Y)

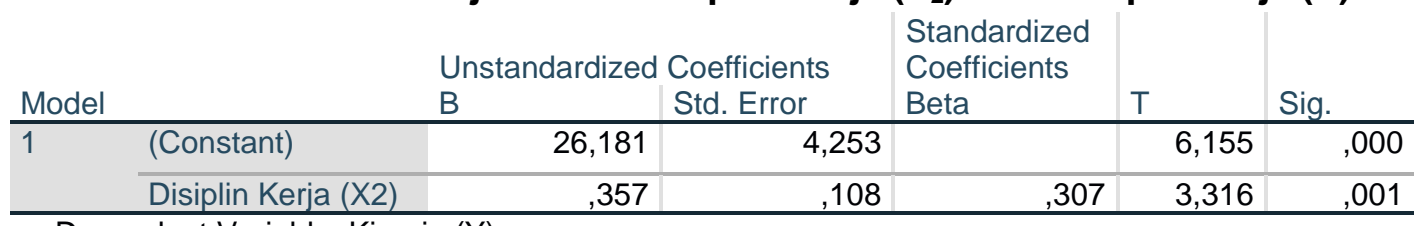

a. Dependent Variable: Kinerja $(\mathrm{Y})$

Sumber : Data Olahan SPSS 24 tahun 2018

Melihat tabel di atas menunjukkan bahwa $t_{\text {hitung }} 3,316>1,983$ dan nilai Sig $0,001<0,05$ maka $\mathrm{H}_{\mathrm{o} 2}$ ditolak dan $\mathrm{H}_{\mathrm{a} 2}$ diterima artinya Terdapat pengaruh positif dan signifikan antara disiplin kerja $\left(\mathrm{X}_{2}\right)$ terhadap kinerja karyawan $(\mathrm{Y})$.

\section{3) Uji Hipotesis Parsial Kompensasi $\left(\mathrm{X}_{3}\right)$ Terhadap Kinerja $(\mathrm{Y})$}

\section{Tabel 4.12 : Hasil Uji Parsial Kompensasi $\left(\mathrm{X}_{3}\right)$ Terhadap Kinerja (Y)}

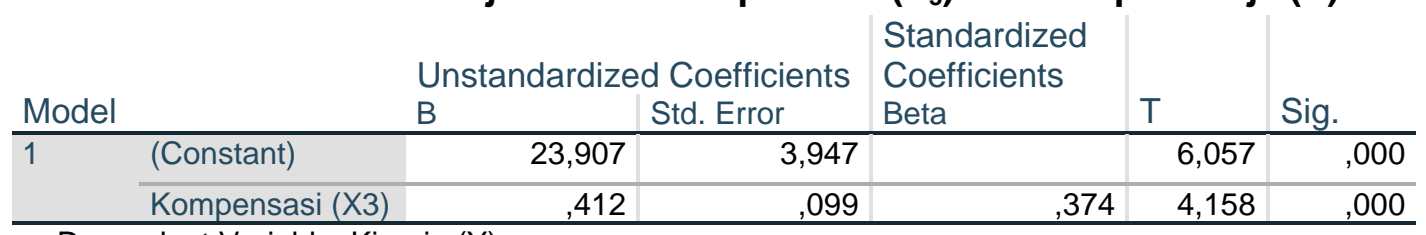

a. Dependent Variable: Kinerja (Y)

Sumber : Data Olahan SPSS 24 tahun 2018

Melihat tabel di atas menunjukkan bahwa $t_{\text {hitung }} 4,158>1,983$ dan nilai Sig $0,000<$ 0,05 maka $\mathrm{H}_{03}$ ditolak dan $\mathrm{H}_{\mathrm{a} 3}$ diterima artinya Terdapat pengaruh positif dan signifikan antara kompensasi $\left(\mathrm{X}_{3}\right)$ terhadap kinerja karyawan $(\mathrm{Y})$. 


\section{b. Uji F Simultan}

Uji statistik $\mathrm{F}$ pada dasarnya menunjukkan apakah semua variabel independen yang dimasukkan dalam model mempunyai pengaruh secara bersama-sama terhadap variabel terikat. Untuk menguji kedua hipotesis ini digunakan uji statistik F. Adapun hipotesis secara simultan yang akan di uji adalah sebagai berikut :

$\mathrm{Ho}_{4}=$ Tidak terdapat pengaruh positif dan signifikan antara kompetensi $\left(X_{1}\right)$, Disiplin Kerja $\left(\mathrm{X}_{2}\right)$ dan Kompensasi $\left(\mathrm{X}_{3}\right)$ terhadap kinerja karyawan $(\mathrm{Y})$

$\mathrm{Ha}_{4}=$ Terdapat pengaruh positif dan signifikan antara kompetensi $\left(X_{1}\right)$, Disiplin Kerja $\left(\mathrm{X}_{2}\right)$ dan Kompensasi $\left(\mathrm{X}_{3}\right)$ terhadap kinerja karyawan $(\mathrm{Y})$

Kaidah pengujian signifikasi :

1) Jika $F_{\text {hitung }} \leq F_{\text {tabel }} 2,69$ atau nilai sig $\geq 0.05$, maka $\mathrm{H}_{04}$ di terima dan $\mathrm{H}_{\mathrm{a} 4}$ di tolak (tidak signifikan).

2) Jika $F_{\text {hitung }}>F_{\text {tabel }} 2,69$ atau nilai sig $<0.05$, maka $\mathrm{H}_{04}$ di tolak dan $\mathrm{H}_{\mathrm{a} 4}$ di terima (signifikan).

Adapun nilai $F_{\text {tabel }}(5 \%, 3,104)=2,69$ (tabel distribusi $F$

Hasil uji F-test seperti pada tabel di bawah ini :

Tabel 4.13 : Output Uji F Simultan

\begin{tabular}{ll|r|r|r|r|r}
$\begin{array}{l}\text { ANOVA } \\
\text { Model }\end{array}$ & Sum of Squares & Df & Mean Square & \multicolumn{1}{c}{ F } & \multicolumn{1}{c}{ Sig. } \\
\hline 1 & Regression & 911,556 & 3 & 303,852 & 11,997 &, $000^{\circ}$ \\
\cline { 2 - 7 } & Residual & 2634,102 & 104 & 25,328 & & \\
\cline { 2 - 7 } & Total & 3545,657 & 107 & & & \\
\hline
\end{tabular}

a. Dependent Variable: Kinerja (Y)

b. Predictors: (Constant), Kompensasi (X3), Kompetensi (X1), Disiplin Kerja (X2)

Sumber : Data Olahan SPSS 24 tahun 2018

Berdasarkan tabel di atas menunjukkan bahwa, pengujian secara simultan antara Kompetensi $\left(\mathrm{X}_{1}\right)$, Disiplin kerja $\left(\mathrm{X}_{2}\right)$, dan Kompensasi $\left(\mathrm{X}_{3}\right)$ terhadap Kinerja $(\mathrm{Y})$ menunjukan nilai $F_{\text {hitung }}$ sebesar 11,997 $>F_{\text {tabel }}$ 2,69 dengan nilai probabilitas Sig $0,000<0,05$ maka dapat disimpulkan bahwa Terdapat pengaruh positif dan signifikan antara kompetensi $\left(X_{1}\right)$, Disiplin Kerja $\left(X_{2}\right)$ dan Kompensasi $\left(X_{3}\right)$ terhadap kinerja karyawan (Y).

Adapun persamaan regresi liniear berganda antara Disiplin Kerja $\left(X_{2}\right)$, Kompetensi $\left(\mathrm{X}_{1}\right)$ dan Kompensasi $\left(\mathrm{X}_{3}\right)$ Terhadap Kinerja $(\mathrm{Y})$ adalah sebagai berikut :

Tabel 4.14 : Output Regresi Linear Berganda Coefficients $^{a}$

\begin{tabular}{|c|c|c|c|c|c|c|}
\hline \multirow{2}{*}{\multicolumn{2}{|c|}{ Model }} & \multicolumn{2}{|c|}{$\begin{array}{l}\text { Unstandardized } \\
\text { Coefficients }\end{array}$} & \multirow{2}{*}{$\begin{array}{l}\text { Standardized } \\
\text { Coefficients } \\
\text { Beta } \\
\end{array}$} & \multirow[b]{2}{*}{$\mathrm{T}$} & \multirow[b]{2}{*}{ Sig. } \\
\hline & & $\mathrm{B}$ & Std. Error & & & \\
\hline \multirow[t]{4}{*}{1} & (Constant) & 4,546 & 6,055 & & ,751 & ,455 \\
\hline & Kompetensi (X1) & ,314 & , 108 & ,250 & 2,909 & ,004 \\
\hline & Disiplin Kerja (X2) & ,236 & , 102 & ,202 & 2,315 & ,023 \\
\hline & Kompensasi (X3) & ,347 & ,095 & ,316 & 3,657 &, 000 \\
\hline
\end{tabular}

a. Dependent Variable: Kinerja (Y)

Sumber : Data Olahan SPSS 24 tahun 2018 
Berdasarkan tabel di atas dapat disimpulkan bahwa terdapat arah hubungan positif antara Kompetensi $\left(\mathrm{X}_{1}\right)$, Disiplin Kerja $\left(\mathrm{X}_{2}\right)$, dan Kompensasi $\left(\mathrm{X}_{3}\right)$ terhadap Kinerja $(\mathrm{Y})$ dengan persamaan Kinerja $(Y)=4,546+0,314 X_{1}+0,236 X_{2}+0,347 X_{3}$.

Sedangkan perhitungan koefisien determinasinya diperoleh hasil seperti pada tabel di bawah ini :

Tabel 4.15 : Output Koefisien Determinasi Kompetensi $\left(X_{1}\right)$, Disiplin $\operatorname{Kerja}\left(\mathrm{X}_{2}\right)$ dan Kompensasi $\left(\mathrm{X}_{3}\right)$ Terhadap Kinerja $(\mathrm{Y})$

\begin{tabular}{|c|c|c|c|c|c|}
\hline Model & $\mathrm{R}$ & R Square & $\begin{array}{l}\text { Adjusted R } \\
\text { Square }\end{array}$ & $\begin{array}{l}\text { Std. Error of the } \\
\text { Estimate }\end{array}$ & Durbin-Watson \\
\hline 1 &, $507^{\mathrm{a}}$ & ,257 & ,236 & 5,033 & 1,879 \\
\hline
\end{tabular}

Nilai R Square sebesar 0,257 diartikan bahwa secara bersama-sama kontribusi atau sumbangan kompetensi, disiplin kerja dan kompensasi terhadap kinerja sebesar $25,7 \%$ dan sisanya $74,3 \%$ dipengaruhi oleh faktor lain.

\section{B. Pembahasan}

1. Pengaruh Kompetensi Terhadap Kinerja

Pengaruh Kompetensi $\left(\mathrm{X}_{1}\right)$ terhadap Kinerja $(\mathrm{Y})$ sebesar $t_{\text {hitung }} 3,335>1,983$ atau nilai Sig 0,001 0,05 maka $\mathrm{H}_{01}$ ditolak dan $\mathrm{H}_{\mathrm{a} 1}$ diterima (Signifikan) artinya Terdapat pengaruh positif dan signifikan antara kompetensi $\left(\mathrm{X}_{1}\right)$ terhadap kinerja karyawan $(\mathrm{Y})$. Nilai $\mathrm{R}$ Square sebesar 0,95 diartikan bahwa kontribusi atau sumbangan kompetensi terhadap kinerja sebesar 9,5\% dan sisanya 90,5\% dipengaruhi oleh faktor lain.

Hasil penelitian ini sesuai dengan penelitian yang telah dilakukan oleh Rozi Fadillah, Sulastini, dan Noor Hidayati (2017) dengan hasil menunjukkan bahwa hasil pengujian membuktikan kompetensi berpengaruh signifikan terhadap kinerja karyawan cabang Bank Banjarmasin di Kalimantan Selatan, dengan pengaruh besar sebesar 66\%.

Menurut Ruky dalam Sutrisno (2016:208) mengemukakan konsep kompetensi menjadi semakin popular dan sudah banyak digunakan oleh perusahaanperusahaan besar dengan berbagai alasan, yaitu: model kompetensiakan mampu menjawab dua pertanyaan mendasar: keterampilan, pengetahuan dan karakteristik apa saja yang dibutuhkan dalam pekerjaan, dan perilaku apa saja yang berpengaruh langsung dengan prestasi kerja.

2. Pengaruh Disiplin Kerja Terhadap Kinerja

Pengaruh Disiplin Kerja $\left(\mathrm{X}_{2}\right)$ terhadap Kinerja $(\mathrm{Y})$ sebesar $\mathrm{t}_{\text {hitung }} 3,316>1,983$ atau nilai Sig 0,001 $<0,05$ maka $\mathrm{H}_{\mathrm{o} 2}$ ditolak dan $\mathrm{H}_{\mathrm{a} 2}$ diterima (Signifikan) artinya terdapat pengaruh positif dan signifikan antara disiplin kerja $\left(\mathrm{X}_{2}\right)$ terhadap kinerja karyawan (Y).Nilai $\mathrm{R}$ Square sebesar 0,94 diartikan bahwa kontribusi atau sumbangan disiplin kerja terhadap kinerja sebesar 9,4\% dan sisanya $90,6 \%$ dipengaruhi oleh faktor lain. Hasil penelitian ini sesuai dengan penelitian oleh Bungawati (2016) dengan hasil menunjukkan bahwa Disiplin kerja berpengaruh signifikan terhadap kinerja guru dengan koefisien 0,301 dan sig $=0,008<0,05$. Hal ini berarti bahwa semakin baik disiplin kerja maka kinerja guru akan semakin baik. 
Hasil penelitian ini sesuai dengan teori yang ada berdasarkan pendapat Hasibuan (2013:23) kedisiplinan merupakan fungsi manejemen sumber daya manusia yang terpenting dan kunci terwujudnya tujuan karena tanpa disiplin yang baik sulit terwujud tujuan yang maksimal.

\section{Pengaruh Kompensasi Terhadap Kinerja}

Pengaruh kompensasi $\left(\mathrm{X}_{3}\right)$ terhadap Kinerja $(\mathrm{Y})$ sebesar $\mathrm{t}_{\text {hitung }} 4,158>1,983$ atau nilai Sig $0,000<0,05$ maka $\mathrm{H}_{03}$ ditolak dan $\mathrm{H}_{\mathrm{a} 3}$ diterima (Signifikan) artinya terdapat pengaruh positif dan signifikan antara kompensasi $\left(\mathrm{X}_{3}\right)$ terhadap kinerja karyawan $(\mathrm{Y})$. Nilai $\mathrm{R}^{2}=0,140$ diartikan kontribusi yang diberikan atau sumbangan kompetensi terhadap kinerja sebesar $14 \%$ dan sisanya $86 \%$ dipengaruhi oleh faktor lain. Hasil penelitian ini sesuai dengan penelitian yang telah dilakukan oleh Fahrul Riza, Mukhlis Yunus, dan Rusli Yusuf (2014) Hasil penelitian menunjukkan bahwa kompensasi, disiplin dan lingkungan kerja non fisik baik secara simultan maupun parsial mempunyai pengaruh terhadap motivasi kerja pegawai kontrak administrasi.

Hasil ini sejalan dengan apa yang telah dikemukakan oleh Wirawan (2012:27) bahwa upah merupakan tolak ukur kinerja karyawan, upah diberikan setelah karyawan menghasilkan kinerja tertentu. Salah satu motivasi yang diberikan perusahaan adalah pemberian kompensasi bagi karyawan, selain itu pemberian kompensasi juga bertujuan untuk mempertahankan karyawan dan meningkatkan kinerja karyawan dalam suatu organisasi.

4. Pengaruh Kompetensi, Disiplin Kerja dan Kompensasi Terhadap Kinerja

Berdasarkan analisa data yang telah dilakukan dapat disimpulkan bahwa, Terdapat arah hubungan positif antara Disiplin Kerja $\left(X_{2}\right)$, Kompetensi $\left(X_{1}\right)$ dan Kompensasi $\left(X_{3}\right)$ terhadap Kinerja $(Y)$ dengan persamaan Kinerja $Y=4,546+0,314$ $X_{1}+0,236 X_{2}+0,347 X_{3}$.

Pengujian secara simultan antara Kompetensi $\left(X_{1}\right)$, Disiplin kerja $\left(X_{2}\right)$, dan Kompensasi $\left(X_{3}\right)$ terhadap Kinerja $(Y)$ menunjukan nilai $F_{\text {hitung }}$ sebesar 11,997 $>F_{\text {tabel }}$ 2,69 dengan nilai probabilitas Sig $0,000<0,05$ maka $\mathrm{Ho}_{4}$ di tolak dan $\mathrm{Ha}_{4}$ di terima, maka dapat disimpulkan bahwa terdapat pengaruh positif dan signifikan antara kompetensi $\left(\mathrm{X}_{1}\right)$, Disiplin Kerja $\left(\mathrm{X}_{2}\right)$ dan Kompensasi $\left(\mathrm{X}_{3}\right)$ terhadap kinerja karyawan (Y). Nilai $\mathrm{R}$ Square sebesar 0,257 diartikan bahwa secara bersama-sama kontribusi atau sumbangan kompetensi, disiplin kerja dan kompensasi terhadap kinerja sebesar $25,7 \%$ dan sisanya $74,3 \%$ dipengaruhi oleh faktor lain.Dari ketiga varabel bebas, yang memberikan kontribusi atau sumbangan paling besar adalah kompensasi dengan kontribusi sebesar $14 \%$ dan kontribusi terkecil adalah kopetensi dengan kontribusi atau sumbangan sebesar 9,5\%. Hasil penelitian ini sesuai dengan penelitian yang telah dilakukan oleh Hamlan Daly (2015) dengan hasil menunjukkan bahwa kompetensi, disiplin, kompensasi secara simultan dan parsial berpengaruh positif dan signifikan terhadap kinerja kepegawaian di kantor wilayah pemberdayaan perempuan dan keluarga berencana, Provinsi Sulawesi Tengah.

Hasil ini sesuai dengan pendapat yang dikemukakan oleh beberapa ahali, diantaranya Ruky dalam Sutrisno (2016:208) mengemukakan konsep kompetensi menjadi semakin popular dan sudah banyak digunakan oleh perusahaan-perusahaan besar dengan berbagai alasan, yaitu: model kompetensi akan mampu menjawab dua 
pertanyaan mendasar: keterampilan, pengetahuan dan karakteristik apa saja yang dibutuhkan dalam pekerjaan, dan perilaku apa saja yang berpengaruh langsung dengan prestasi kerja. Menurut Hasibuan (2013:23) kedisiplinan merupakan fungsi manejemen sumber daya manusia yang terpenting dan kunci terwujudnya tujuan karena tanpa disiplin yang baik sulit terwujud tujuan yang maksimal. Wirawan (2012:27) bahwa upah merupakan tolak ukur kinerja karyawan, upah diberikan setelah karyawan mengahasilkan kinerja tertentu. Salah satu motivasi yang diberikan perusahaan adalah pemberian kompensasi bagi karyawan, selain itu pemberian kompensasi juga bertujuan untuk mempertahankan karyawan dan meningkatkan kinerja karyawan dalam suatu organisasi.

\section{KESIMPULAN DAN SARAN}

\section{A. Kesimpulan}

1. Terdapat pengaruh positif dan signifikan antara kompetensi $\left(X_{1}\right)$ terhadap kinerja karyawan $(\mathrm{Y})$.

2. Terdapat pengaruh positif dan signifikan antara disiplin kerja $\left(\mathrm{X}_{2}\right)$ terhadap kinerja karyawan $(Y)$.

3. Terdapat pengaruh positif dan signifikan antara Kompensasi $\left(\mathrm{X}_{3}\right)$ Terhadap Kinerja Karyawan $(Y)$

4. Terdapat pengaruh positif dan signifikan secara simultan antara Kompetensi $\left(X_{1}\right)$, Disiplin Kerja $\left(X_{2}\right)$ dan Kompensasi $\left(X_{3}\right)$ Terhadap Kinerja dengan persamaan regresi linier berganda $: Y=4,546+0,314 X_{1}+0,236 X_{2}+0,347$ $\mathrm{X}_{3}$. Secara simultan kontribusi atau sumbangan kompetensi, disiplin kerja dan kompensasi terhadap kinerja sebesar $25,7 \%$ dan sisanya $74,3 \%$ dipengaruhi oleh faktor lain. Dari ketiga varabel bebas, yang memberikan kontribusi atau sumbangan paling besar adalah kompensasi dengan kontribusi sebesar $14 \%$ dan kontribusi terkecil adalah kompetensi dengan kontribusi atau sumbangan sebesar $9,5 \%$.

\section{B. Saran}

1. PT. Moranthel Indonesia Gemilang harus memberikan motivasi kepada karyawan untuk lebih meningkatkan minatnya dalam melanjutkan pendidikan yang lebih tinggi agar menambah pengetahuan dan pemahaman.

2. PT. Moranthel Indonesia Gemilang harus selalu memberikan sosialisasi tentang peraturan kerja kepada Karyawan agar lebih taat dan mematuhi standar kerja, meningkatkan kerjasama serta memahami sistem gaji dan upah yang berlaku di perusahaan.

\section{DAFTAR PUSTAKA}

Bangun, Wilson. 2012. Manajemen Sumber Daya Manusia, Erlangga, Bandung

Ghozali. Imam. 2013. Analisis Multivariate. Penerbit : Universtitas Dipenegoro. Semarang

Griffin, Ricky W, 1980, Relationships Among Individual, Task Design, and Leader Behavior Variables", Academy of Management Journal, Vol.23, No.4, 665-683 
Hutapea, Parulian dan Nurianna Thoha. 2008. Kompetensi Plus. Jakarta: PT GramediaPustaka Utama

Nawawi, H. Hadari. 2011. Manajemen Sumber Daya Manusia untuk Bisnis yang. Kompetitif. Yogyakarta: Gajah Mada University Press

Handoko, T. Hani. 2013. ManajemenSumber Daya Manusia Perusahaan, BPFEYogyakarta

Hasibuan. S. P Malayu. 2013. Manajemen Sumber Daya Manusia. Penerbit : Bumi Aksara. Jakarta

Mangkunegara. Prabu Anwar. 2013. Manajemen Sumber Daya Manusia Perusahaan. Penerbit : Remaja Rosdakarya. Bandung

Mathis, Robert L \& John, Jackson H. 2008. Human Resource Management, edisi 10. Salemba Empat, Jakarta Salemba Empat, Jakarta.

Moeheriono. 2009. Pengukuran Kinerja Berbasis Kompetensi. Bogor: Ghalia

Noelaka. Amos. 2015. Metode Penelitian Dan Statistik.Penerbit :Remaja Rosdakarya. Jakarta

Ramdhani, Arif, 2011. Penilaian Kinerja. PT Sarana Panca Karya Nusa, Bandung

Riduwan, dan Akdon. 2009. Aplikasi Statistika dan Metode Penelitian untuk. Administrasi dan Manajemen, Dewa Ruci Bandung

Robbins \& Coulter. 2007. Manajemen. Indeks.Jakarta

Rivai, Veitzal. 2008. Manajemen Sumber Daya Manusia untuk Perusahaan: Dari. Teori ke Praktik, Rajagrafindo Persada, Jakarta

Simamora. Henry. 2014. Manajemen Sumber Daya Manusia. Penerbit : YKPN. Yogyakarta

Siregar. Syofian. 2014. Satatistik Parametrik Untuk Penelitian Kuantitatif, Penerbit : Bumi Aksara. Jakarta

Sobirin, Ahmad. 2014. Budaya Organisasi. UPP Sekolah Tinggi IlmuManajemen YKPN. Yogyakarta

Sugiyono. 2010. Metode Penelitian Bisnis. Cetakan ke 15 Alfabet. . Bandung

Sutrisno. Edy. 2016.Manajemen Personalia Dan Manajemen Sumber Daya Manusia. Penerbit : Prenada Media Group. Jakarta

Suwatno, \& Priansa, Donni Juni. 2011. Manajemen Sumber Daya Manusia, Dalam Organisasi Publik dan Bisnis. Alfabeta, Bandung:

Wibowo. 2016.Manajemen Kinerja. Jakarta : PT. Rajagrafindo Persada.

Wirawan, 2012. Evaluasi Kinerja Sumberdaya Manusia, Teori Aplikasi dan Penelitian, Jakarta, Salemba Empat

Yuniarsih Tjuju \& Suwanto. 2011. Manajemen Sumber Daya Manusia. Alfabeta.Bandung 